\title{
Intellectual disability in the Esidimeni tragedy: Silent deaths
}

Esidimeni means 'place of dignity'. It now signifies the disaster in which people continue to die (140 at last count) and go missing after being transferred from Life Esidimeni into the care of nongovernmental organisations (NGOs). $\cdot^{[1-3]}$

Esidimeni is not only a medical maladministration scandal. It is a story about the sociopolitical abuse of people who only matter once they die. Patients are not dead because they were mentally ill or simply medically mismanaged. They died because we are careless. We do not care enough to be clear about the difference between people with mental or psychiatric illness and people with intellectual disability (PWID) (no longer called mentally retarded). Countless Esidimenis are currently happening to people who are still alive. The extent of neglectful and abusive care will again only come to light once they also die of starvation, dehydration, cold and infection. Abominable as the crisis is, it is our (current) high-water mark of an ongoing silent catastrophe, which implies that abuse of the living matters less, if at all, than being neglected to death. It also comments on our nation. We profess to know about discrimination and resultant inequality, yet the PWID at the centre of the Esidimeni tragedy are of the single most disenfranchised and oppressed groups in our society.

\section{Intellectual disability is not a mental illness}

Despite the current national 'Esidimeni deaths' discourse, it is not widely understood that at least half of the deceased lived with severe to profound intellectual disability (ID). ${ }^{[4]}$ While psychiatric illnesses frequently accompany ID, these are different conditions and can exist separately. People who live with ID and a comorbid mental illness live with a dual diagnosis. People can live with ID and not have a mental illness. ${ }^{[5]}$ To refer to PWID as being mentally ill obscures distinctions between mental illness and ID, and dismisses particular abilities, vulnerabilities, and care and support needs of individuals who live with either or both.

\section{Adults with intellectual disability are not children}

Most adults with ID in South Africa (SA) are treated as children. ${ }^{[6]}$ This disabling practice translates into undignified and abusive treatment. To justify giving children's NGOs licences to accept adults, Dr M Manamela repeated that 'mentally ill adult patients have the mind of a child, so they could be classified as children. ${ }^{[1]}$ Firstly, a $\mathrm{PhD}$ in psychiatric nursing should afford one the competence to differentiate mental illness from ID, as mentioned above. Secondly, infantilising adults with ID is ironic: in SA they do not enjoy protections similar to children. The Mental Health Care Act No. 17 of 2002 and its General Regulation Amendment lack rights governance for adults with any level of ID living in community settings. ${ }^{[7]}$ No law similar to the Children's Act No. 38 of 2005 intervenes on behalf of adults. ${ }^{[8]}$ Government is not legally required to intercede in the best interests of vulnerable adults at risk of abuse, neglect and death.

\section{The problem with measuring tragedy in deaths}

Esidimeni has been measured in deaths from the start - a tragedy of 94, then $112 \ldots 137$ and so on. ${ }^{[4]}$ Measuring the disaster's enormity by counting deaths is illogical. If the 'problem' is only as large as the number of deaths, then there is 'no tragedy' if one survives unthinkable abuse and neglect. If people died because of inhuman(e) care, be sure of two things: 140 people suffered horrifically until they died, and many more are still enduring appalling trauma. By measuring tragedy in deaths, we reveal a binary appreciation of intellectually disabled lives in which 'alive or dead' is the only meaningful statistic. This leaves no space for questioning the quality of life of living people and dehumanises PWID.

\section{For love or money?}

The NGOs are tasked with the complex care and support needs of intellectually disabled patients, but without sufficient budgets. Faced with this impossibility, it is instead asserted that, above all, 'these people need love'. Turning NGOs into saintly providers of good deeds to the wretched of the earth obscures the cost of this 'love'. NGOs accept money to care for these adults. Globally, dependency carers should be paid and trained better, but we cannot create the perception that selfless carers are accepting the needs burdens of PWID out of love. Unhelpfully pitting their needs against one other creates a conflict of interest between paid carers and their burdensome 'charges'.

This 'love' can be reframed as the effort of emotion work - affective investment in another's well-being - during the performance of care labour. ${ }^{\left[{ }^{9-11]}\right.}$ In a caring society, dependency care relationships are ones of interdependence and mutual respect. The hardest physical work does not result in good care if the point of caring is task completion, regardless of the well-being of care participants. ${ }^{[12]}$

\section{Avoiding future Esidimeni-like catastrophes}

We are in a perpetual care crisis. The current tragedy is an outcome of sweeping, structurally embedded social injustices that will mark us in history if we continue to ignore them. We must face the distressing reality that Esidimeni-like rights violations happen to PWID on a daily basis in pervasive ways. ${ }^{[13]}$ Rights violations against PWID will not stop after one arbitration. For lives of PWID to matter more than death, the following attitudinal changes must infuse ID rights systemisation and implementation:

\section{Practical/systemic risk mitigation solutions}

- Specialist residential care is not inexpensive, but provides a service that the state is unable or unwilling to fulfil. The rapid withdrawal of support for PWID from such care must not be repeated.

- SA lawmakers must educate themselves on what intellectual disabilities actually mean', as gazetted in parliament. ${ }^{[14]}$

- The dualist legal system incorporates into domestic laws the United Nations Convention of the Rights of Persons with Disabilities, which SA signed 10 years ago. ${ }^{[15]}$

- A Vulnerable Adults Act legally obliges the state to perform universal safeguarding of adults with ID beyond the inadequate Mental Health Care Act No. 17 of 2002. ${ }^{\text {7] }}$

- Well-regulated community care requirements for PWID are collaboratively approached with urgency by the Department of Social Development and the Department of Health, in consultation with self-advocates, so as to:

- remedy lacking public residential care facilities for people with severe and profound ID in particular

- uphold the constitutional right PWID have to life, and bodily and psychological integrity. ${ }^{[16]}$ 
- Designated ID care facilities are built-for-purpose. Care staff are up-skilled or renewed.

- Service initiatives investigate and adapt recognised international policies and guidelines pertaining to good clinical practice and organisational design.

- With an eye to the future, the implementation of the Draft South African Policy Framework for the Provision of Quality Education and Support for Children with Severe to Profound Intellectual Disability is ensured. ${ }^{[17]}$

- The transversal treatment of PWID is integrated throughout the public healthcare system. Safe task-shifting to community-based resources takes place. Families caring for adult members with ID are supported.

- Appropriate sociopolitical inclusion of PWID and their families begins at birth. Monitoring is lifelong by care and support plans.

- The remuneration and training of carers, nurses and other multidisciplinary team members must urgently be overhauled. SA offers specialised ID training, and all health-related training programmes will incorporate more than a few hours of ID training.

- De-medicalised ID training becomes an interdisciplinary competence. PWID are consulted on their treatment preferences by integrated practitioners. Future service designs incorporate the expertise of PWID and their families. Continuous professional development requirements keep registered practitioners up-todate on best practice. Trainers with ID broaden practitioner understanding.

- Cost-free relational processes balance commodified care of PWID. We consider the purpose and individualisation of care, as well as the power relations integral to all dependency care relationships. ${ }^{[12]}$

\section{Attitudinal risk mitigation solutions}

- We overcome our avoidance of the must-have national conversation on disability exclusion.

- PWID are enfranchised and contribute to politicising disability issues, as exemplified elsewhere. ${ }^{[18-20]}$ The estimated SA population is $55908865 .{ }^{[21]}$ With an approximated prevalence of $4.1 \%$, $>2000000$ individuals may be living with ID in SA ${ }^{[21,22]}$ Legislators will vie in future for the sociopolitical approval of $>2$ million PWID in SA.

- We acknowledge that ID care also unfolds in boardrooms and policy documents. During scarce resource distributions we question whose needs are being accommodated - 'ours' or 'theirs'.

- Opinions are collected from PWID on issues that directly affect their lives. They are included in policy design. ${ }^{[9-12]}$

- PWID compel good care performance. They select their own carers as their self-identified needs change. ${ }^{[9-12]}$

- Systemic and national ID work is infused by ethics of care practice that helps government and society change one another's responses to ID.

- Ethics of care starts conversations about engaging with people who need help and about our interdependent, inevitable need for care. In our caring society anyone may accept assistance without feeling bad.

- We attend to the institutional forms and practices through which we express care. We reject bad ID care and unscrupulous resource distribution. We object to professional power inequalities that leave us feeling uncared for. ${ }^{[12]}$ We do so free from patronisation or retribution.

Avoiding future Esidimenis necessitates competent medical administration. It also requires recognition that ID care means much more than completing tasks without deaths occurring. We take care by thinking about how we undermine opportunities for PWID to live enriching, meaningful and torture-free lives. We care by conducting ourselves constitutionally in our common humanity. Bad care dehumanises PWID by nullifying their material and psychological needs. Good care honours PWID by increasing interpersonal compensation and reassurance because individual powers have failed. ${ }^{[23]}$ Justice D Moseneke said to Dr M Manamela: 'Maybe you just didn't care!! ${ }^{[1]}$ Our point exactly.

\section{Capri}

Division of Intellectual Disability, Department of Psychiatry and Mental Health, University of Cape Town, South Africa

charlotte.capri@uct.ac.za

\section{B Watermeyer, J Mckenzie}

Division of Disability Studies, Department of Health and Rehabilitation Sciences, University of Cape Town, South Africa

\section{O Coetzee}

Division of Intellectual Disability, Department of Psychiatry and Mental Health, University of Cape Town, South Africa

1. Child K. Judge Moseneke to Esidimeni tragedy official: 'Maybe you just didn't care!' TimesLive, 23 November 2017. https:/www timeslive.co.za/news/south-africa/2017-11-23-judge-moseneke-to-esidimenitragedy-official-maybe-you-just-didnt-care/ (accessed 25 November 2017)

2. Chabalala Pijoos $I 4$ of 144 patients do not form part of Life Esidimeni arbitration process - ombudsman. Chabalala J, Pijoos I. 4 of 44 patients do not form part of Life Esidimeni arbitration process - ombudsman. News24, 6 February 2018. htps://www.news24.com/SouthAfrica/News/4-of-144-patients-do-not-form19 February 2018)

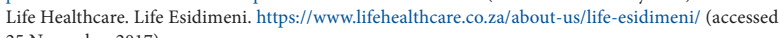
5 November 2017)

Makgoba MW. The report into the circumstances surrounding the deaths of mentally ill patients: Gauteng Province - no guns: 94+ silent deaths and still counting. Republic of South Africa: Health Ombud. 2016. https://www.sahrc.org.za/home/21/files/Esidimeni\%20full\%20report.pdf (accessed 19 December 2016).

5. American Psychiatric Association. Diagnostic and Statistical Manual of Mental Disorders (DSM-5), Washington, DC: APA, 2013

6. Capri CH, Swartz L. 'We are actually, after all, just children': Caring societies and South African infantilisation of adults with intellectual disability. Disabil Soc 2018;33(2):285-308. https://doi.org/10.108 0/09687599.2017.1409102

Republic of South Africa. Mental Health Care Act No. 17 of 2002.

8. Republic of South Africa. Children's Act No. 38 of 2005.

9. Kittay EF When caring is just and justice is caring: Justice and mental retardation. Public Culture 2001;13(3):557-579. https://doi.org/10.1215/08992363-13-3-557

10. Kittay EF. The personal is philosophical is political: A philosopher and mother of a cognitively ditay EF. The personal is philosophical is political: A philosopher and mother of a cognitively
disabled person sends notes from the battlefield. Metaphilosophy 2009;40(3-4):606-627. https://doi. disabled person sends notes from the bat

1. Kittay EF, Jennings B, Wasunna AA. Dependency, difference and the global ethic of longterm care. J Polit Philos 2005;13(4):443-469. https://doi.org/10.1111/j.1467-9760.2005.00232.x

12. Tronto JC. Creating caring institutions: Politics, plurality, and purpose. Ethics Soc Welfare 2010;4(2):158-171. https://doi.org/10.1080/17496535.2010.484259

13. Drew N, Funk M, Tang S, et al. Human rights violations of people with mental and psychosocial disabilities: An unresolved global crisis. Lancet 2011;378(9803):1664-1675. https://doi.org/10.1016/ s0140-6736(11)61458-x

14. Department of Social Development, South Africa. Draft First Periodic Country Report on the United Nations Convention on the Rights of Persons with Disabilities (UNCRPD). Government Gazette No. 38802:445. 2015.

15. United Nations. Convention on the Rights of Persons with Disabilities (A/RES/61/106). Resolution adopted by the General Assembly on 13 December 2006. New York: UN, 2006

6. Republic of South Africa. Constitution of the Republic of South Africa: Chapter 2 - the Bill of Rights, Act No. 108 of 1996.

17. Department of Basic Education, South Africa. Call for written submissions from stakeholder bodies Department of Basic Education, South Africa. Call for written submissions from stakeholder bodies
and members of the public on the draft policy for the provision of quality education and support for children with severe to profound intellectual disability. Government Gazette No. 40375:48. 2016.

18. Hood I. How will Scots with learning disabilities be voting in the referendum? The Guardian, 16 September 2016. https://www.theguardian.com/society/2014/sep/16/scots-learning-disabilitiesindependence-referendum (accessed 1 November 2016).

19. Kjellberg A, Hemmingsson H. Citizenship and voting: Experiences of persons with intellectual disabilities in Sweden. J Pol Prac Intel Disab 2013;10(4):326-333. https://doi.org/10.1111/jppi.12056

20. The Electoral Commission (United Kingdom). Voters with a disability are reminded there should be no barriers to them casting their vote on 7 May 2015. http://www.electoralcommission.org.uk (accessed 1 November 2016)

21. World Bank. South Africa Overview: World Bank Group. 2017. http://www.worldbank.org/en/ country/southafrica/overview (accessed 7 August 2017).

22. Statistics South Africa. Census 2011: Profile of persons with disabilities in South Africa. http://www. statssa.gov.za/publications/Report-03-01-59/Report-03-01-592011.pdf (accessed 21 August 2015).

23. Morris J. Impairment and disability: Constructing an ethics of care that promotes human rights. Hypatia 2001;16(4):1-6. https://doi.org/10.1353/hyp.2001.0059 